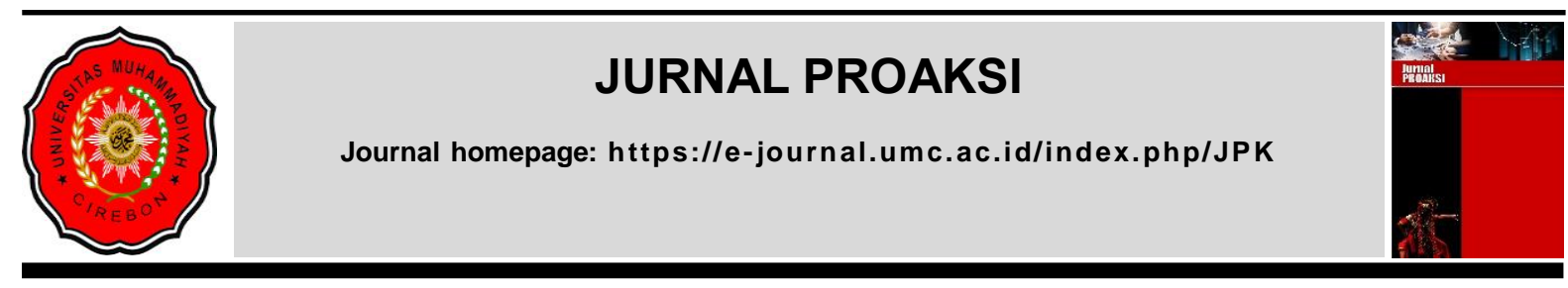

\title{
GENDER MEMODERASI FINANCIAL LITERACY DAN FINANCIAL BEHAVIOR TERHADAP KETAHANAN KEUANGAN RUMAH TANGGA MILENIAL SELAMA PANDEMI COVID-19
}

\author{
Andira Sucianah ${ }^{1}$ \\ Indrawati Yuhertiana ${ }^{*}$ \\ ${ }^{1}$ Fakultas Ekonomi dan Bisnis, Universitas Pembangunan Nasional "Veteran" Jawa Timur \\ Email :andira19062020019.mak@student.upnjatim.ac.id \\ ${ }^{2}$ Fakultas Ekonomi dan Bisnis, Universitas Pembangunan Nasional "Veteran" Jawa Timur \\ *Corresponden Author Email : yuhertiana@gmail.com
}

Diterima : 21 Juli 2021

Direvisi : 2 Agustus 2021

Dipublikasikan : 17 Oktober 2021

\begin{abstract}
Abstrak
Tujuan dari penelitian ini adalah untuk menguji dan menganalisis pengaruh financial literacy dan financial behavior terhadap ketahanan keuangan rumah tangga generasi millennial dengan gender sebagai variabel moderasi selama pandemi Covid-19. Dengan diterapkan berbagai kebijakan untuk mengurangi penularan Covid-19, mengakibatkan dampak negatif terhadap kinerja pertumbuhan ekonomi. Merosotnya kinerja pertumbuhan ekonomi, disebabkan adanya sektor ekonomi rumah tangga dari sisi konsumsi, yang diakibatkan penurunan tingkat pendapatan, pengambilan keputusan keuangan serta perilaku keuangan yang kurang bijak. Penelitian ini merupakan penelitian kuantitatif dan populasi yang digunakan dalam penelitian ini adalah generasi millennial di kota Surabaya. Teknik pengambilan sampel yang digunakan adalah cluster random sampling terhadap anggota populasi tersebut, dimana ukuran sampel minimal berdasarkan penggunaan rumus slovin yaitu 100 sampel dari keseluruhan anggota populasi. Metode pengumpulan data menggunakan kuesioner. Metode analisis data yang digunakan adalah Structural Equation Modeling (SEM). Hasil penelitian menunjukkan bahwa semakin literasi keuangan suatu keluarga, maka meningkatkan ketahanan keuangan suatu keluarga dan semakin baik perilaku keuangan yang dimiliki suatu keluarga maka meningkatkan ketahanan keuangan suatu keluarga. Sedangkan gender bukan variable pemoderasi pengaruh literasi keuangan dan perilaku keuangan terhadap ketahanan keuangan.
\end{abstract}

Kata Kunci : Literasi Keuangan, Perilaku Keuangan, Ketahanan Keuangan, Gender

\section{PENDAHULUAN}

Pada Desember 2019, dunia dihebohkan dengan sebuah kejadian yang diduga sebuah kasus pneumonia yang etiologinya tidak diketahui yang kasus tersebut berasal dari Kota Wuhan, China. Virus jenis baru tersebut selanjutnya dikenal dengan sebutan (SARS-CoV-2) dan penyakitnya disebut sebagai Corona Disease 2019 (Covid-19) (Ervina et al., 2020). Peningkatan kasus positif yang terjadi dari hari ke hari menyebabkan banyak kerugian terhadap berbagai sektor di Indonesia membuat Para pengambil kebijakan di setiap Negara mengambil langkah cepat untuk mengurangi semakin banyaknya warga yang tertular wabah ini. Salah satu cara memutus mata rantai penularan, melalui penerapan social distancing yang bertujuan agar mencegah orang yang sakit untuk kontak dalam jarak 2 meter dengan orang yang sehat agar tidak terjadi penularan (Komara et al., 2020).

Kebijakan tersebut mengharuskan orang-orang untuk melakukan semua aktivitasnya dari rumah, sehingga menimbulkan gangguan pada rantai pasok input, operasi produksi, rantai distribusi, dan pemasaran output sehingga berdampak negatif terhadap kinerja pertumbuhan ekonomi (Budastra, 
2020). Badan Pusat Statistik (BPS) dikutip Modjo (2020) menyebutkan Angka pertumbuhan Produk Domestik Bruto (PDB) Indonesia pada triwulan-1 2020 tercatat hanya sebesar 2,97 (year-on-year) yang merupakan angka pertumbuhan terendah sejak 2001. Pada triwulan-2 2020 angka realisasi pertumbuhan ekonomi jauh lebih buruk dari perkiraan pemerintah, yang memprediksi pertumbuhan ekonomi pada kuartal II akan berada di level minus 3,1\% dan realisasinya ada di angka minus 5,32 \%. Adapun pada kuartal III pertumbuhan Indonesia menurun hingga minus 3,49 \%. Kondisi di kuartal III lebih baik dari kontraksi terdalam kuartal sedangkan triwulan-4 menunjukkan arah pemulihan (BPS, 2020).

Merosotnya PDB Indonesia tersebut disebabkan adanya penurunan sektor ekonomi rumah tangga dari sisi konsumsi yang cukup tajam. BPS mencatat konsumsi rumah tangga mengalami kontraksi sebesar minus 3,61 \% di kuartal IV-2020. Secara akumulatif 2020, konsumsi rumah tangga mengalami kontraksi sebesar minus 2,63\%. Penurunan tajam pada belanja rumah tangga konsumen disebabkan oleh dua hal: meningaktnya jumlah penggangguran dan adanya ketidakpastian akibat pandemi Covid-19 menyebabkan dialihkannya konsumsi pada tabungan (precautionary savings) oleh rumah tangga yang pendapatannya belum terlalu terdampak dari krisis akibat pandemi ini (Modjo, 2020).

Berdasarkan Survei oleh Lembaga Ilmu Pengetahuan Indonesia (LIPI) terhadap 1.548 responden di 32 provinsi, mengungkap 64,8\% rumah tangga pekerja dan 87,3\% rumah tangga usaha mengalami kesulitan keuangan akibat pandemi COVID-19, baik rumah tangga pekerja maupun usaha (Antaranews, 2020). Tingginya membiayai pengeluaran rumah tangga di masa pandemic merupakan akibat dari tidak bijak dalam mengelola keuangan dan pengambilan keputusan keuangan, seperti terjadinya pemborosan yang merugikan keuangan keluarga dan tidak melakukan perencanaan keuangan yang baik (Suarni dan Sawal, 2020)

Sejalan dengan penelitian Indonesia Millennial Report oleh Otoritas Jasa Keuangan (OJK) pada tahun 2019 yang menyatakan sebanyak 51\% uang milenial dihabiskan untuk keperluan konsumtif, 10,7 $\%$ digunakan untuk menabung terakhir hanya $2 \%$ yang digunakan untuk investasi. Akibatnya dari perilaku konsumtif, milenial mengakibatkan cenderung gagal dalam mengelola keuangan mereka (Azizah, 2020). Melihat fenomena tersebut, adanya pandemi covid-19, keluarga milenial dengan pertahanan keuangan yang rapuh hanya bisa bertahan beberapa minggu dan berpotensi menciptakan situasi hidup tak menentu yaitu meningkatnya hutang keluarga (Kalla dan Sahara, 2020). Keluarga perlu untuk beradaptasi dengan adanya perubahan-perubahan, masalah dan tantangan yang terjadi dalam menghadapi pandemic covid-19. Keluarga dituntut untuk memiliki ketahanan financial agar dapat mengatasi setiap permasalahan yang dihadapinya demi kelangsungan perekonomian keluarga (Kristiyani dan Khatimah, 2020). Ketahanan financial rumah tangga dipandang sebagai sebuah proses yang dijalani di sepanjang kehidupan keluarga sehingga anggota di dalam keluarga perlu bersinergi dalam menjalani kehidupan.

Salah satu faktor yang mempengaruhi ketahanan keuangan rumah tangga adalah financial literacy. Tingkat financial literacy seseorang akan memengaruhi bagaimana seseorang menabung, berhutang, melakukan investasi, dan mengatur keuangannya (Ida et al., 2020). Faktor selanjutnya yang dinilai mempengaruhi ketahanan keuangan adalah financial behavior. Financial behavior dalam rumah tangga yakni tindakan untuk merencanakan, melaksanakan, memonitor, mengevaluasi, dan mengendalikan perolehan dan penggunaan sumber-sumber ekonomi keluarga khususnya keuangan agar tercapai tingkat pemenuhan kebutuhan seluruh anggota keluarga secara optimum. Terkait hal tersebut maka Financial behavior menjadi suatu pilihan yang sebaiknya dimiliki oleh seseorang untuk bertahan menghadapi situasi saat ini (Sina, 2020).

Di dalam pengetahuan dan perilaku keuangan, bagi laki-laki dan perempuan memiliki karakteristiknya masing-masing. Hal tersebut dipengaruhi oleh bentukan social budaya sehingga tercipta pembagian peran antara laki-laki dan perempuan yang dipandang sesuai dengan adat istiadat, norma dan kebiasaan masyarakat yang disebut gender. Gender menimbulkan perbedaan dalam mengelola keuangan pribadi dan keluarga (Putri \& Asrori, 2019). Dalam penelitian terdahulu yang dilakukan oleh Sabri et al., (2017) dan Yusri (2018) menyebutkan bahwa gender memoderasi pengaruh literasi keuangan dan perilaku keuangan tetapi dalam penelitian Putri \& Asrori, (2019) dan Yulinar et al., (2020) menyebutkan bahwa peran gender tidak mampu memoderasi pengaruh literasi keuangan dan perilaku keuangan. Untuk itu, dalam penelitian ini, peneliti memasukan gender sebagai variabel moderasi untuk menjawab dari ketidakkonsistenan hasil dari variable financial literacy dan financial behavior terhadap ketahanan keuangan rumah tangga. 
Tujuan dari penelitian ini adalah untuk menganalisis pengaruh financial literacy dan financial behavior terhadap ketahanan keuangan rumah tangga generasi milenial dan untuk menganalisis peran gender dalam memoderasi pengaruh financial literacy dan financial behavior terhadap ketahanan keuangan rumah tangga generasi milenial selama pandemi covid-19. Penelitian ini diharapkan memberikan kontribusi sebagai sumber informasi, sarana edukasi bagi generasi milenial, supaya lebih bijak dalam mengelola keuangan.

\section{KAJIAN TEORI}

\section{Theory of Planned Behaviour}

Theory of Planned Behaviour (TPB) atau Teori Perilaku Terencana merupakan perluasan dari Theory of Reasoned Action (TRA) atau Teori tindakan beralasan. Dalam TRA dijelaskan bahwa niat seseorang terhadap perilaku dibentuk oleh dua faktor utama yaitu attitude toward the behaviour dan subjective norms Fishbein dan Ajzen, 1975 dalam (Djou, 2019)

TRA kemudian dikembangkan oleh Ajzen pada tahun 1991, teori tersebut dikenal dengan Theory of Planned Behaviour (TPB). TPB menganggap bahwa teori sebelumnya mempunyai keterbatasan, yaitu hanya dimaksudkan untuk menjelaskan perilaku-perilaku yang akan dikerjakan secara sukarela, bukan perilaku-perilaku yang diwajibkan. TPB mengembangkan dan memperkuat TRA dengan menambahkan sebuah variabel yaitu pengendalian perilaku persepsian (perceived behavioural control) untuk mengontrol halangan-halangan internal dan eksternal dalam melakukan perilaku (Handika dan Sudaryanti, 2018).

Berdasarkan TPB mengasumsikan bahwa seseorang berperilaku dengan cara yang sadar maupun tidak sadar dan mempertimbangkan informasi yang tersedia. Dengan banyaknya informasi keuangan yang dimiliki oleh individu tersebut, dapat membedakan pilihan keuangan, mendiskusikan problem keuangan tanpa adanya ketidaknyamanan, menanggapi kompeten, perencanaan masa depan serta serta melakukan keputusan keuangan lainnya. Berdasarkan TPB, perilaku dipengaruhi oleh niat berperilaku individu, sikap dan perasaan individu tentang kemampuan mengontrol segala sesuatu yang mempengaruhi apabila hendak melakukan perilaku tersebut. Sehingga timbulnya perilaku keuangan karena adanya dampak besar dari keinginan individu dalam pemenuhan kesejahteraan hidup individu sesuai tingkat penghasilan yang diperolehnya (Herlina Budiono, 2019).

\section{Financial Literacy}

Menurut Wijayangka (2018) literasi keuangan terdiri dari sejumlah kemampuan dan pengetahuan mengenai keuangan yang dimiliki oleh seseorang untuk dapat mampu mengelola atau menggunakan sejumlah uang untuk meningkatkan taraf hidupnya. (Remund, 2010) menambahkan literasi keuangan adalah kemampuan seseorang untuk memahami dan menggunakan masalah keuangan. Artinya, literasi keuangan adalah kemampuan seseorang dalam memahami dan menggunakan masalah keuangan (Dai, 2021).

Litearasi keuangan yang baik juga bisa meminimalkan terjadinya keputusan yang salah terhadap isu ekonomi dan keuangan yang muncul. Sedangkan dari sudut pandang penyedia jasa keuangan, literasi keuangan yang baik akan memberikan infromasi yang memadai mengenai produk, pemahaman risiko pada pelanggan dan efisiensi efisiensi biaya. Selanjutnya dari sudut pandang pemerintah, dengan literasi keuangan yang baik pada masyarakat, pemerintah dapat memperoleh pamasukan pajak dengan maksimal untuk pengembangan infrastruktur dan fasilitas pelayanan public.

Berdasarkan beberapa pengertian diatas, dapat diambil kesimpulan literasi keuangan bagi masyarakat luas tidak hanya sekedar memahami dan mengetahui tentang jasa, produk maupun lembaga keuangan, melainkan juga dapat mengubah perilaku masyarakat luas dalam mengelola keuangan sehingga mampu meningkatkan kesejahteraan hidup ke arah yang lebih baik.

\section{Financial Behavior}

Financial behavior (perilaku keuangan) muncul pada tahun 1990-an sejalan dengan tuntuan perkembangan dunia bisnis dan akademik yang mulai menyikapi adanya aspek atau unsur perilaku dalam proses pengambilan keputusan keuangan dan investasi. Financial behavior adalah keterlibatan perilaku yang ada pada diri seseorang yang meliputi emosi, sifat, kesukaan dan berbagai macam hal yang melekat dalam diri manusia sebagai makhluk intelektual dan sosial yang berinteraksi dan melandasi munculnya keputusan melakukan suatu tindakan (Kusnandar dan Kurniawan, 2020). 
Menurut Fitriani dan Widodo (2020) financial behavior atau perilaku keuangan yang mempelajari keputusan keuangan, salah satunya psikologi dalam keputusan keuangan, perusahaan dan pasar keuangan. Hal ini muncul dari dampak besarnya emosi seseorang untuk memenuhi kebutuhan hidupnya sesuai dengan pendapatannya. Pada saat menentukan keputusan keuangan, diharapkan dapat secara rasional dan relevan dalam mendapat informasi sehingga dapat mengoptimalkan keputusan.

Lebih lanjut menurut (Hasibuan et al., 2018) Perilaku keuangan juga didefinisikan sebagai seberapa baik suatu rumah tangga atau individu mengelola sumber daya keuangan yang meliputi perencanaan anggaran tabungan, asuransi dan investasi. Perilaku keuangan seseorang dapat dilihat dari seberapa baik dia mengelola uang tunai, hutang, tabungan dan pengeluaran lainnya.

Berdasarkan beberapa definisi dari perilaku keuangan di atas maka dapat disimpulkan bahwa perilaku keuangan adalah ilmu yang menjelaskan mengenai perilaku individu yang berhubungan dengan bagaimana individu memperlakukan, mengelola, mengatur dan menggunakan sumber daya keuangan yang ada padanya. Individu yang memiliki perilaku keuangan yang bertanggung jawab cenderung efektif dalam penggunaan uang yang dimilikinya, seperti membuat anggaran, menghemat uang dan mengontrol belanja, berinvestasi.

\section{Ketahanan Keuangan}

Ketahanan Keuangan (Financial Resilience) didefinisikan oleh Klapper dan Lusardi (2020) sebagai kemampuan untuk menahan peristiwa kehidupan yang berdampak pada pendapatan dan / atau aset seseorang. Dikutip dalam (Pandin et al., 2021), menyatakan bahwa ketahanan finansial adalah kemampuan untuk pulih lebih cepat dari guncangan ekonomi yang dihadapi sebuah rumah tangga.

Bank of International Settlements (BIS) dikutip oleh Amalia et al., (2020) menambahkan ketahanan ekonomi keluarga merupakan kemampuan keluarga dalam bidang ekonomi untuk cepat pulih dari goncangan dan masalah yang merugikan dan mengandung dampak ketidakseimbangan dalam keuangan. Ketahanan ekonomi bukan hanya tentang bagaimana keluarga mampu bertahan dari masalah keterpurukan dalam bidang ekonomi, namun juga tentang bagaimana cara untuk meningkatkan penghasilan dalam keluarga.

Berdasarkan definisi tersebut, ketahanan keuangan rumah tangga adalah sebuah kemampuan untuk bertahan hidup dan menghadapi peristiwa yang terjadi dan berdampak terhadap penghasilan atau aset rumah dan kemampuan untuk pulih lebih cepat dari goncangan ekonomi yang dihadapi dalam rumah tangga.

\section{Peran Gender}

Pengertian gender menurut Fakih dalam jurnal (Giovano et al., 2020) adalah suatu sifat yang melekat pada kaum laki-laki maupun perempuan yang dikonstruksi secara social maupun kultural. Misalnya, perempuan dikenal lemah lembut, cantik, emosional, atau keibuan, sementara laki-laki dianggap kuat, rasional, jantan, atau perkasa. Ciri dari sifat itu sendiri merupakan sifat-sifat yang dapat dipertukarkan.

Peran dan kontribusi gender terhadap ekonomi keluarga cukup memegang peranan penting. Keterlibatan laki-laki dan perempuan dapat dioptimalkan apabila faktor penghambat yang melingkupinya teridentifikasi dengan baik. Kerjasama laki-laki dan perempuan dalam konteks rumah tangga memberikan gambaran pentingnya peran gender dalam setiap rumah tangga untuk menentukan keberlangsungan ketahanan ekonomi dalam hidup rumah tangganya (Pical et al., 2020).

\section{Pengaruh Financial Literacy Terhadap Ketahanan Keuangan Rumah Tangga}

Financial literacy merupakan modal awal sebuah keluarga untuk bertahan dalam situasi tak terduga, dengan kata lain sebuah keluarga mampu beradaptasi dan bertahan ketika terjadi guncangan apabila keluarga tersebut mempunyai pengetahuan dan pemahaman yang baik dalam keuangan, sehingga mampu merespon dan menganalisis dengan tepat suatu kejadian yang terkait dengan keuangan Dengan financial literacy yang baik, sebuah keluarga memahami semua resiko keuangan yang akan terjadi, sehingga keluarga mampu beradaptasi dan tetap teguh di masa sulit dan minimal tidak mengalami kesulitan karena mampu membuat keputusan keuangan yang dapat meminimalisasi terjadinya risiko (Syarifah, 2016). Menurut Laksono et al., (2019) semakin tinggi tingkat literasi finansial semakin tinggi pula tingkat ketahanan keuangan keluarga. Artinya sebuah keluarga dengan literasi finansial yang baik, mampu menciptakan manajemen keuangan yang sehat dan lebih mampu 
membuat keputusan keuangan yang baik, sehingga mengarah pada ketahanan keuangan yang baik. Hal tersebut sejalan dengan hasil penelitian Ervina et al., (2020), Pandin et al., (2021) dan Sabri et al., (2017).

H1 : Financial literacy berpengaruh positif terhadap ketahanan keuangan rumah tangga.

\section{Pengaruh Financial Behavior Terhadap Ketahanan Keuangan Rumah Tangga}

Perilaku keuangan yang positif dapat meningkatkan ketahanan keuangan, artinya keberhasilan dalam mengelola keuangan keluarga sangat dipengaruhi oleh perilaku personal didalam keluarga (suami-istri), pengetahuan atau pemahaman cara mengelolaan, gaya hidup dan tujuan keuangan (tujuan jangka pendek, menengah dan panjang dari keluarga) (Chakma 2017). Hasil penelitian Chakma (2017) menyatakan bahwa dengan adanya perilaku keuangan yang baik, seperti menabung dan berinvestasi dapat membangun ketahanan keuangan rumah tangga. Sejalan dengan hasil penelitian Pandin et al., (2021) yang menyatakan bahwa perilaku keuangan berpengaruh terhadap ketahanan keuangan.

$\mathrm{H} 2$ : Financial behavior berpengaruh positif terhadap ketahanan keuangan rumah tangga.

\section{Peran Gender Memoderasi Pengaruh Financial Literacy Terhadap Ketahanan Keuangan Rumah Tangga}

Norma gender dapat menyebabkan perbedaan antara pria dan wanita sehubungan dengan financial literacy. Perbedaan tingkat literasi antara laki-laki dan perempuan akan memberikan perbedaan dalam mengelola keuangan pribadinya, dengan literasi keuangan yang tinggi maka akan bijak dalam pengambilan keputusan keuangan, hasilnya keluarga tersebut mampu bertahan dalam segala situasi atau minimal tidak mengalami kesulitan keuangan. Perbedaan tingkat literasi antara lakilaki dan perempuan akan memberikan perbedaan dalam mengelola keuangan keluarga, dengan literasi keuangan yang tinggi maka akan bijak dalam pengambilan keputusan keuangan, hasilnya keluarga tersebut mampu bertahan dalam segala situasi atau minimal tidak mengalami kesulitan keuangan. Pernyataan tersebut didukung oleh hasil penelitian Sabri et al., ( 2017), Škreblin et al., (2017) dan Yuliani et al., (2020) yang menyatakan gender memperkuat pengaruh literasi keuangan.

H3 : Peran gender memperkuat pengaruh financial literacy terhadap ketahanan keuangan.

\section{Peran Gender Memoderasi Pengaruh Financial Behavior Terhadap Ketahanan Keuangan Rumah Tangga}

Keberhasilan dalam mengelola keuangan keluarga sangat dipengaruhi oleh perilaku personal didalam keluarga (suami-istri), pengetahuan atau pemahaman cara pengelolaan, gaya hidup dan tujuan keuangan. Berdasar jurnal Putri dan Asrori (2019) disebutkan bahwa tingkah laku seorang individu dalam bersikap terhadap perilaku keuangan sesuai dengan gender, dimana perempuan lebih tekun dalam mempelajari konsep keuangan dan lebih rajin dalam pembuatan perencanaan keuangan, dan lebih berhati-hati dalam pengelolaan keuangan. Hal ini mengarah dalam pertimbangan kehati-hatian untuk menentukan pilihan dalam pengambilan keputusannya. Dalam jurnal Yogasnumurti et al., (2020) menyatakan bahwa perilaku pria cenderung lebih rasional dalam membelanjakan uang dibandingkan perempuan yang lebih didasarkan pada faktor kesenangan semata. Hal tersebut juga didukung pernyataan Ansong dan Gyensare dalam Laily (2016) mengungkapkan bahwa laki-laki lebih pandai dalam mengelola keuangan dibandingkan dengan perempuan. Hal tersebut mengindikasikan bahwa peran gender memoderasi pengaruh financial behavior terhadap ketahanan keuangan. Berdasarkan penjelasan yang telah dijabarkan, maka hipotesis yang dapat disimpulkan adalah peran gender memperkuat pengaruh financial behavior terhadap ketahanan keuangan.

H4 : Peran gender memperkuat pengaruh financial behavior terhadap ketahanan keuangan.

\section{METODE PENELITIAN}

Metode kuantitatif menjadi metode yang dilakukan pada penelitian ini, dengan skala likert dengan pilihan lima (tidak pernah, hampir tidak pernah, kadang-kadang, sering, dan selalu). Populasi pada penelitian ini yaitu masyarakat gerenasi milenial Kota Surabaya sebanyak 69,900 jiwa. Maka dari itu penentuan sampel dengan rumus slovin dengan hasil 100 sampel, dengan criteria sudah berumah tangga, tahun kelahiran 1981-1995. Model analisis data yang dilakukan yaitu dengan SEM (Structural Equation Modeling) dengan salah satu metode Partial Least Square (PLS) dengan menggunakan software SmartPLS 3.0. 


\section{HASIL PENELITIAN DAN PEMBAHASAN \\ Hasil Penelitian}

Pada karakteristik responden dalam penelitian ini $100 \%$ laki-laki dan perempuan yang sudah menikah dengan persentase jenis kelamin adalah $44 \%$ laki-laki dan $56 \%$ perempuan. Latar belakang lulus S1 mendominasi sebesar 75\% diikuti lulus SMA/Sederajat sebesar 21\% sisanya sebesar 4\% lulus S2. Sebanyak 55\% pekerjaan responden adalah pegawai swasta, 19\% ibu rumah tangga, 12\% wiraswasta, $8 \%$ aparatur sipil Negara (ASN) dan 6\% pegawai BUMN. Dengan tingkat pendapatan Rp. 3.000.000 - Rp. 4.999 .000 mendominasi sebesar 46\%, Rp. 5.000.000 - Rp. 7.999 .000 sebesar 23\%, Rp. 2.000.000 - Rp. 2.999 .000 sebesar 22\%, Rp. 8.000 .000 - Rp. 10.000.000 sebesar 5\% dan sisanya Di atas Rp. 10.000.000 sebesar 4\%. Penelitian ini menggunakan uji validitas dan reliabilitas untuk menguji kelayakan instrumen. Uji validitas convergen dinyatakan baik ketika indikator dari konstruk mempunyai nilai loading paling tinggi pada kelompok atau kolomnya. Berikut hasil pengujian kualitas data dengan uji convergent validity:

Tabel 1. Uji Validitas

\begin{tabular}{lcc}
\hline \multicolumn{1}{c}{ Konstruk } & Nilai AVE & Hasil \\
\hline Financial Literacy & 0,706 & Valid \\
\hline Financial Behavior & 0,640 & Valid \\
\hline Ketahanan Keuangan & 0,788 & Valid \\
\hline Gender & 1,000 & Valid \\
\hline
\end{tabular}

Sumber : Hasil Pengolahan Data Primer dengan SmartPLS 3.0

Berdasarkan hasil uji validitas diatas, seluiruh hasil uji validitas konvergen menunjukkan nilai AVE $>0.5$ sehingga seluruh konstruk dalam penelitian dinyatakan valid. Adapun untuk hasil outer loading standart yang digunakan adalah diatas 0.7

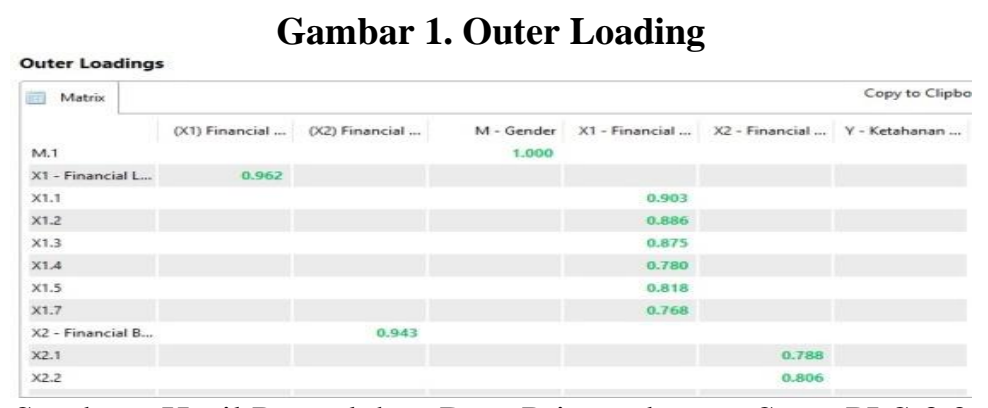

Sumber : Hasil Pengolahan Data Primer dengan SmartPLS 3.0

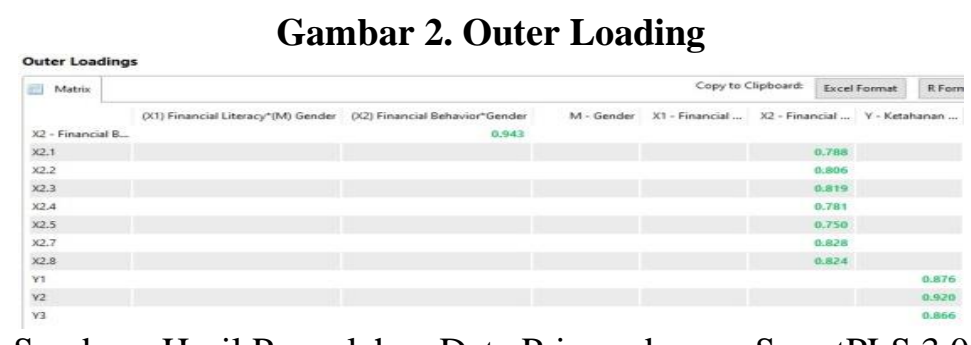

Sumber : Hasil Pengolahan Data Primer dengan SmartPLS 3.0

Uji reliabilitas diukur dari nilai Composite Reliability (CR) dan Cronbach Alpha (CA), yang mencerminkan konsistensi internal alat ukur. Aturan yang umum dipakai untuk menentukan suatu instrumen reliabel adalah melihat nilai $\mathrm{CR} \geq 0.7$ dan $\mathrm{CA} \geq 0.7$. Penelitian ini akan membandingkan nilai $C R$ dan CA untuk memilih mana yang paling tinggi nilainya maka itu yang akan digunakan sebagai hasil uji reliabilitas. Berdasarkan hasil uji reliabilitas diatas, seluruh hasil uji reliabilitas menunjukkan nilai Cronbach alpha melebihi 0.6 sehingga seluruh konstruk dalam penelitian tersebut adalah valid dan dapat digunakan untuk melakukan pengujian lanjutan. 
Tabel 2 Uji Validitas

\begin{tabular}{lccc}
\hline \multicolumn{1}{c}{ Konstruk } & CA & CR & Ket \\
\hline Financial Literacy & 0,916 & 0,935 & Valid \\
\hline Financial Behavior & 0,906 & 0,925 & Valid \\
\hline Ketahanan Keuangan & 0,868 & 0,918 & Valid \\
\hline Gender & 1,000 & 1,000 & Valid \\
\hline
\end{tabular}

Sumber : Hasil Pengolahan Data Primer dengan SmartPLS 3.0

\section{Pengujian Hipotesis}

Pengujian hipotesis diuji dengan menggunakan path analysis. Berdasarkan hipotesis 1 diketahui bahwa pengaruh financial literacy terhadap ketahanan keuangan adalah diterima dengan path estimate $=0.448, t$-value $=3.075$, dan $p$-value $<0.002$. Berdasarkan hipotesis 2 diketahui bahwa financial behavior berpengaruh terhadap ketahanan keuangan adalah diterima dengan path estimate $=0.370, t$ value $=2.862$, dan $p$-value $<0.004$. Berdasarkan hipotesis 3 diketahui bahwa peran gender memoderasi pengaruh financial literacy terhadap ketahanan keuangan adalah ditolak dengan path estimate $=0.055$, $t$-value $=0.323$, dan $p$-value $<0.747$. Berdasarkan hipotesis 4 diketahui bahwa peran gender memoderasi pengaruh financial behavior terhadap ketahanan keuangan adalah ditolak dengan path estimate $=0.018$, $t$-value $=0.143$, dan $p$-value $<0.886$.

\section{Gambar 3. Kerangka PLS}

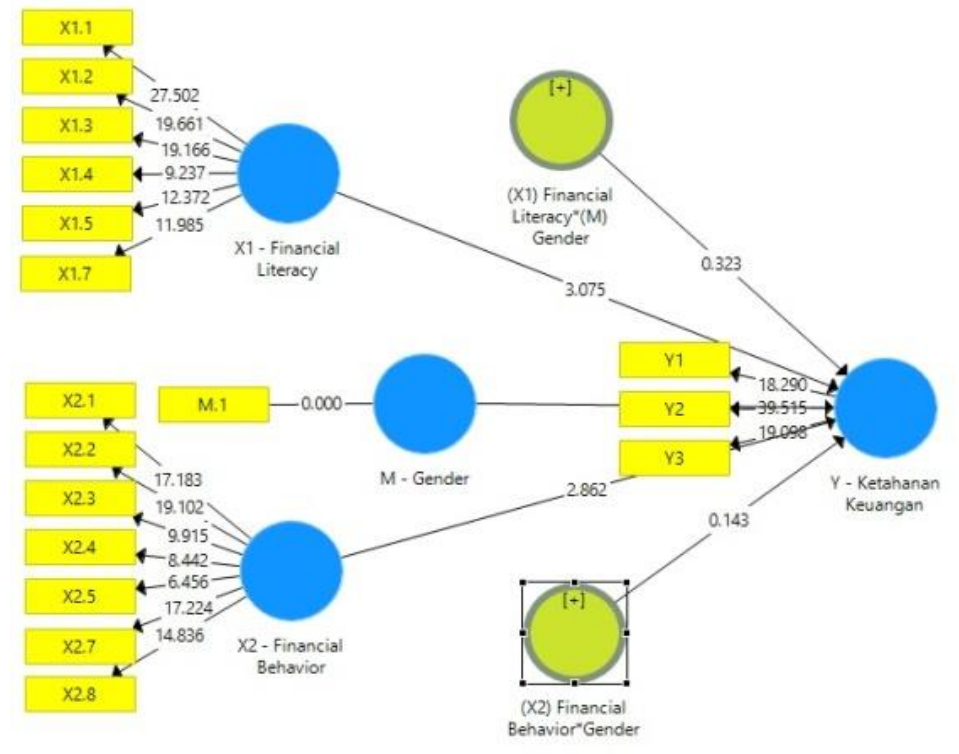

Sumber : Hasil Pengolahan Data Primer dengan SmartPLS 3.0

\section{PEMBAHASAN}

\section{Pengaruh Financial Literacy Terhadap Ketahanan Keuangan Rumah Tangga}

Berdasarkan hasil pengujian penelitian didapat bahwa financial literacy berpengaruh positif dan signifikan terhadap ketahanan keuangan rumah tangga, sehingga H1 diterima. Artinya, tingkat financial literacy yang tinggi, akan mempengaruhi ketahanan keuangan sebuah keluarga. Keluarga dengan literasi finansial yang baik, mampu menciptakan manajemen keuangan yang sehat dan lebih mampu membuat keputusan keuangan yang baik, sehingga mengarah pada ketahanan financial yang baik. Dengan financial literacy pula, keluarga dapat menggunakan pengetahuan dan kemampuannya untuk mengevaluasi risiko keuangan sehingga keputusan keuangan yang dihasikan nantinya tidak menambah kesulitan dalam keluarga, Sedangkan rumah tangga generasi milenial yang kurangnya literasi keuangan akan cenderung lebih memiliki masalah dengan hutang, lebih terlibat dengan biaya kredit yang lebih tinggi karena mereka cenderung tidak memiliki dana cadangan untuk hidup mereka. Sehingga kecil kemungkinannya untuk merencanakan masa depan, dan kecil kemungkinan akan mampu beradaptasi di tengah kondisi pandemic. 
Hasil penelitian tersebut memberikan gambaran bahwa generasi milenial di Surabaya memahami pentingnya literasi keuangan bukan karena untuk mempersulit dalam menggunakan uang yang dimiliki, tetapi harapan suatu keluarga dapat menikmati hidup dengan menggunakan sumber daya keuangan yang dimiliki dengan tepat dan benar sehingga keluarga tersebut masih bertahan dan mampu membuat perencanaan masa depan atas peristiwa-peristiwa yang berpengaruh pada keputusan keuangan berjangka, termasuk kejadian perekonomian secara umum. Dalam TBP dijelaskan bagaimana seseorang dapat melakukan suatu tindakan keuangan dengan cara yang sadar maupun tidak sadar dan mempertimbangkan informasi yang tersedia. Maka individu dengan tingkat literasi keuangan yang tinggi, akan membuat keputusan keuangan yang bijak, sehingga dalam kondisi pandemic tidak kesulitan keuangan minimal mampu bertahan. Hal tersebut sejalan dengan hasil penelitian Ervina et al., (2020), Pandin et al., (2021) dan Sabri et al., (2017).

\section{Pengaruh Financial Behavior Terhadap Ketahanan Keuangan Rumah Tangga}

Berdasarkan hasil pengujian penelitian didapat bahwa financial literacy berpengaruh positif dan signifikan terhadap ketahanan keuangan rumah tangga, sehingga $\mathrm{H} 2$ diterima. Artinya, tingkat financial literacy yang tinggi, akan mempengaruhi ketahanan keuangan sebuah keluarga. Keluarga dengan financial behavior yang baik, akan lebih dapat membelanjakan pendapatannya dengan bijaksana untuk hal-hal yang dibutuhkan dan mereka terbiasa menyisihkan pendapatannya sehingga di masa pandemic saat ini mereka mampu beradaptasi minimal tidak mengalami kesulitan. Karena pengelolaan keuangan ditatanan kenormalan baru tidaklah mudah dan munculnya beberapa perubahan bisa mengganggu stabilitas keuangan keluarga, untuk itu dengan pola perilaku keuangan yang baik akan memberikan perlindungan sebagai bentuk kemampuan beradaptasi di kemudian hari jika terjadi hal-hal yang tidak diinginkan (Aulia, 2020). Hasil penelitian penelitian Chakma (2017) menyatakan bahwa dengan adanya perilaku keuangan yang baik, seperti menabung dan berinvestasi dapat membangun ketahanan keuangan rumah tangga. Sejalan dengan hasil penelitian Pandin et al., (2021) yang menyatakan bahwa financial behavior berpengaruh terhadap ketahanan keuangan.

\section{Peran Gender Pengaruh Financial Literacy Terhadap Ketahanan Keuangan Rumah Tangga}

Berdasarkan hasil pengujian penelitian didapat bahwa peran gender tidak mampu memoderasi pengaruh financial literacy terhadap ketahanan keuangan, sehingga $\mathrm{H} 3$ ditolak. Penelitian ini menunjukkan bahwa baik laki-laki maupun perempuan tidak memiliki perbedaan dalam memahami informasi keuangan. Laki-laki dituntut untuk memiliki tingkat financial literacy tinggi, agar dapat membimbing keluarga untuk membuat keputusan terbaik terkait dengan uang agar keluarganya mampu beradaptasi di masa pandemic ini. Sedangkan perempuan dengan tingkat financial literacy tinggi akan lebih rajin dalam pembuatan perencaan keuangan dan lebih hemat dalam penggunaan uang. Akan tetapi di Era milenial ini, perempuan generasi millennial bersemangat melanjutkan pendidikan tinggi bahkan sudah banyak terhitung perempuan melanjutkan ke tingkat magister bahkan doktor. Sangat berbeda sekali ketika masa sebelum generasi millennial, dimana pendidikan masih didominasi oleh laki-laki, ditambah dengan akrabnya generasi milenial dengan tekonologi informasi yang dimanfaatkan untuk mengakses mengenai pengetahuan keuangan, sehingga di generasi milenial ini tingkat pemahaman konsep-konsep keuangan antara laki-laki dan perempuan tidak ada perbedaan yang signifikan, atas hal tersebut maka laki-laki dan perempuan terus berusaha dan belajar memahami pengetahuan dan informasi keuangan agar keluarganya tidak mengalami kesulitan, sehingga antara laki-laki dan perempuan mempunyai kemampuan dan pengetahuan yang setara. Hal tersebut sejalan dengan hasil penelitian (Putri \& Asrori, 2019) dan (Yulinar et al., 2020).

\section{Peran Gender Pengaruh Financial Behavior Terhadap Ketahanan Keuangan Rumah Tangga}

Berdasarkan hasil pengujian penelitian didapat bahwa peran gender tidak mampu memoderasi pengaruh financial behavior terhadap ketahanan keuangan, sehingga $\mathrm{H} 4$ ditolak. Hal tersebut mengindikasikan bahwa perilaku keuangan seseorang yang baik tidak dilihat dari gender. Tingkah laku seorang individu dalam bersikap terhadap perilaku keuangan tidak melihat dari segi sudut pandang gender. Di zaman serba canggih ini, baik laki-laki dan perempuan tidak lagi mengalami kesulitan dalam mengelola keuangan dan lebih rasional dalam membelanjakan pendapatan. Ditunjang dengan tingkat pendidikan tinggi, maka laki-laki dan perempuan mampu menganalisis sebelum memutuskan untuk membeli suatu barang atau jasa pada tingkat harga tertentu. Walaupun perempuan memiliki tingkat analisis yang cukup tinggi sebelum memutuskan untuk membeli suatu barang atau jasa pada tingkat 
harga tertentu dan laki-laki cenderung mengutamakan kepuasan pribadi dalam hal membeli barang sesuai dengan keinginannya, tetap peran gender tidak mampu membedakan antara perempuan dan lakilaki di dalam mengelola keuangan rumah tangga. sehingga perempuan belum tentu memiliki kemampuan pengelolaan keuangan tinggi ataupun sebaliknya laki-laki belum tentu memiliki kemampuan pengelolaan keuangan yang rendah. Sehingga dapat dikatakan, perempuan belum tentu memiliki perilaku keuangan yang baik ataupun sebaliknya laki-laki belum tentu memiliki perilaku keuangan yang kurang baik. Hal tersebut sejalan dengan hasil penelitian (Putri \& Asrori, 2019).

\section{KESIMPULAN}

Hasil dari peneitian ini menunjukkan bahwa financial literacy dan financial behavior berpengaruh terhadap ketahanan keuangan rumah tangga generasi milenial. Artinya, semakin baik financial literacy dan didukung dengan adanya financial behavior yang bijak, maka meningkatkan ketahanan keuangan suatu keluarga. Namun, peran gender tidak mampu memoderasi pengaruh financial literacy dan financial behavior terhadap ketahanan keuangan rumah tangga generasi milenial. Hal tersebut dikarenakan dalam generasi milenial, zaman sudah serba canggih, jadi laki-laki dan perempuan tidak lagi mengalami kesulitan dalam mengelola keuangan dan lebih rasional dalam membelanjakan pendapatan. Ditunjang dengan tingkat pendidikan tinggi, maka laki-laki dan perempuan mampu menganalisis sebelum memutuskan untuk membeli suatu barang atau jasa pada tingkat harga tertentu, sehingga gender tidak mampu memoderasi pengaruh financial literacy dan financial behavior berpengaruh terhadap ketahanan keuangan rumah tangga.

\section{SARAN}

1. Saran Teoritis: Bagi peneliti selanjutnya, memperbanyak jumlah sample dengan memperluas wilayah populasi, tidak hanya Kota Surabaya.

2. Saran Praktis: Bagi generasi milenial, hendaknya memanfaatkan kecanggihan teknologi sebagai media informasi untuk meningkatkan pengetahuan keuangan dan sarana edukasi dalam menerapkan pola manajemen keuangan yang baik, supaya tidak mengalami kesulitan keuangan di tengah pandemic covid-19. Sehingga kecanggihan teknologi tidak hanya dimanfaatkan untuk perilaku konsumtif.

\section{REFERENSI}

Amalia, L., \& Lindiasari Samputra, P. (2020). Strategi Ketahanan Ekonomi Keluarga Miskin Penerima Dana Bantuan Sosial Di Kelurahan Tanah Tinggi Jakarta Pusat. Sosio Konsepsia, 9(2), 113-131. https://doi.org/10.33007/ska.v9i2.1792

Antaranews. (2020). Dampak Pandemi COVID-19 Terhadap Ekonomi Rumah Tangga. Https://Www.Antaranews.Com/.

Azizah, N. S. (2020). Pengaruh literasi keuangan, gaya hidup pada perilaku keuangan pada generasi milenial. Prisma (Platform Riset Mahasiswa Akuntansi), 01(02), 92-101.

BPS. (2020). Statistik Pertumbuhan Ekonomi Indonesia Triwulan I-2020. Www.Bps.Go.Id, 17, 2.

Budastra, I. K. (2020). Socio-Economic Impacts of Covid-19 and Potential Programs for Mitigation : a Case Study in Lombok Barat District. Jurnal Agrimansion, 20(1), 48-57.

Chakma, N. (2017). The savings and investment behavior of extreme poor Marma community households in resilience building : a case study on Green Hill village savings and loan association intervention in the Chittagong Hill Tracts. 19, 33.

Dai, R. M. (2021). The Influence of Financial Attitude and Financial literacy on Behavioral Finance: A Study on Leading Small and Medium Enterprises in Cimahi City, Indonesia. Review of Integrative Business and Economics Research, 10(1), 322-329.

Djou, L. G. (2019). Analisis pengaruh literasi keuangan, sikap keuangan dan kepribadian terhadap perilaku pengelolaan keuangan UMKM di Kabupaten Ende. Jurnal Magisma, 7(2), 1-12.

Ervina, R. H., Setyorini, N., \& Sutrisno. (2020). Financial Literacy dan Financial Planning Dampaknya Terhadap Ketahanan Keuangan Keluarga di Masa Pandemi Covid-19. SEMINAR NASIONAL HASIL PENELITIAN (SNHP), 1-12.

Fitriani, A., \& Widodo, A. (2020). Pengaruh Financial Knowledge Terhadap Financial Behavior Dengan Financial Attitude Sebagai Variabel Intervening Pada Generasi Z. Jurnal Ilmiah MEA (Manajemen, Ekonomi, \& Akuntansi), 4(2), 310-319. 
Giovano, A., Satrya Wibowo, A., \& Yanuarisa, E. (2020). PENGARUH LOVE OF MONEY DAN RELIGIUSITAS TERHADAP KECENDERUNGAN FRAUD ACCOUNTING DANA DESA DENGAN GENDER SEBAGAI VARIABEL MODERASI PADA DESA DI KECAMATAN KATINGAN TENGAH. Balance, 12(2), 11-24.

Handika, M. F. D., \& Sudaryanti, D. (2018). Analisis Faktor-Faktor Yang Mempengaruhi Niat Mahasiswa Melakukan Tindakan Whistleblowing. Jurnal Ilmiah Bisnis Dan Ekonomi Asia, 11(1), 56-63. https://doi.org/10.32812/jibeka.v11i1.33

Hasibuan, B. K., Lubis, Y. M., \& HR, W. A. (2018). Financial Literacy and Financial Behavior as a Measure of Financial Satisfaction. 46(Ebic 2017), 503-507. https://doi.org/10.2991/ebic17.2018.79

Herlina Budiono, H. W. Y. I. P. (2019). Keterkaitan Pengetahuan dan Perencanaan Keuangan Terhadap Perilaku Karyawan Pria. Jurnal Ekonomi, 24(2), 176. https://doi.org/10.24912/je.v24i2.567

Ida, I., Zaniarti, S., \& Wijaya, G. E. (2020). Financial Literacy, Money Attitude, Dan Financial Management Behavior Generasi Milenial. Jurnal Muara Ilmu Ekonomi Dan Bisnis, 4(2), 406. https://doi.org/10.24912/jmieb.v4i2.9144

Kalla, T., \& Sahara, N. (2020). Milenial Paling Rentan Alami Masalah Keuangan. Investor.Id.

Kirbiš Škreblin, I., Vehovec, M., \& Galić, Z. (2017). Relationship Between Financial Satisfaction And Financial Literacy: Exploring Gender Differences. Drustvena Istrazivanja, 26(2), 165-185. https://doi.org/10.5559/di.26.2.02

Klapper, L., \& Lusardi, A. (2020). Financial literacy and financial resilience: Evidence from around the world. Financial Management. https://doi.org/10.1111/fima.12283

Komara, B. D., Setiawan, H. C. B., \& Kurniawan, A. (2020). Jalan Terjal UMKM dan Pedagang Kecil Bertahan di Tengah Pandemi Covid-19 dan Ancaman Krisis Ekonomi Global. Jurnal Manajemen Bisnis, 17(3), 1689-1699.

Kristiyani, V., \& Khatimah, K. (2020). Pengetahuan Tentang Membangun Resiliensi Keluarga Ketika Menghadapi Pandemi Covid-19. Jurnal Abdimas, 6(4), 232-237.

Kusnandar, D. L., \& Kurniawan, D. (2020). Literasi Keuangan Dan Gaya Hidup Ibu Rumah Tangga Dalam Membentuk Perilaku Keuangan Di Tasikmalaya. SAINS: Jurnal Manajemen Dan Bisnis, XIII(1), 123-143.

Laily, N. (2016). Pengaruh Literasi Keuangan Terhadap Perilaku Mahasiswa Dalam Mengelola Keuangan. Journal of Accounting and Business Education, 1(4). https://doi.org/10.26675/jabe.v1i4.6042

Laksono, B. A., Supriyono, S., \& Wahyuni, S. (2019). Tinjauan Literasi Finansial dan Digital pada Tingkat Ketahanan Keluarga Pekerja Migran Indonesia. Jurnal Penelitian Kesejahteraan Sosial, $18(2), 123-134$.

Modjo, M. I. (2020). Memetakan Jalan Penguatan Ekonomi Pasca Pandemi. The Indonesian Journal of Development Planning, 4(2), 2321. https://doi.org/10.33758/mbi.v14i4.342

Pandin, M. Y. R., Ratnawati, T., \& Yuhertiana, I. (2021). The Influence of Financial Structure, Financial Literacy and Financial Behavior on Household Financial Resilience Using Financial Inclusion and Financial Decision as Interverning Variables on Cancer Survivor s Household in East Java During Covid-19 Pandem. IJEBD (International Journal of Entrepreneurship and Business Development), 04(01), 80-90.

Pical, V. J., Nanlohy, H., \& Saiful. (2020). Peran Gender Dan Pengambilan Keputusan Rumah Tangga Perikanan Purse Seine Di Kabupaten Maluku Tengah. 7(14), 74-88.

Putri, A. R., \& Asrori, A. (2019). Determinan Literasi Finansial Dengan Gendersebagai Variabel Moderasi. Economic Education Analysis Journal, 7(3), 894-908. https://doi.org/10.15294/eeaj.v7i3.28318

Remund, D. L. (2010). The influence of financial literacy towards risk tolerance. International Journal of Business and Society, 44(2), 276-295.

Rumbianingrum, W., \& Wijayangka, C. (2018). Pengaruh Literasi Keuangan Terhadap Pengelolaan Keuangan UMKM. JURNAL MANAJEMEN DAN BISNIS (ALMANA), 2(3), 155-165.

Sabri, M. F., Abdullah, N., Zenhendel, M., \& Ahmad, S. Y. (2017). Moderation Effect of Gender on Financial Literacy, Money Attitude, Financial Strains and Financial Capability. Malaysian Journal of Consumer and Family Economics, 20(December), 83-101. 
Sina, P. G. (2020). Ekonomi Rumah Tangga Di Era Pandemi Covid-19. Journal of Management : Small and Medium Enterprises (SMEs), 12(2), 239-254. https://doi.org/10.35508/jom.v12i2.2697

Suarni, A., \& Sawal, A. R. (2020). Peran Akuntansi Dalam Rumah Tangga Dan Penerapan Pengelolaan Keuangan Rumah Tangga Secara Islami Di Masa Pandemi Covid-19. ASSETS, 10(2), 110-129.

Syarifah, Z. (2016). Pengaruh Literasi Keuangan Terhadap Kesejahteraan Keuangan Dengan Mediasi Perilaku Pengelola Keuangan Keluarga. 7, 1-25.

Yogasnumurti, R. R., Sadalia, I., \& Irawati, N. (2020). The Effect of Financial Attitude and Financial Knowledge on Personal Financial Management of University Students Moderated by Gender. International Journal of Research and Review, 7(February), 219-229.

Yoosita Aulia. (2020). Pengelolaan Keuangan Bagi Generasi Milenial Di Era New Normal. In Unitomo Press (Vol. 53, Issue 9).

Yuliani, Fuadah, L. L., \& Taufik. (2020). Moderating Influence of Gender on the Association Between Financial Attitude, Financial Behavior, Financial Knowledge, and Financial Literacy. Altantis Press, 142(Seabc 2019), 356-360. https://doi.org/10.2991/aebmr.k.200520.059

Yulinar, B., Yuliani, \& Umrie, R. H. (2020). Literasi Keuangan Dan Kepuasan Keuangan Dengan Gender Sebagai Moderasi: Studi Pada Mahasiswa Di Kota Palembang. Jurnal Manajemen Dan Bisnis Equilibrium, 6(1), 1-16. https://doi.org/10.47329/jurnal_mbe.v6i1.424

Yusri, A. (2018). Pengaruh Gender dan Kemampuan Akademis Terhadap Perilaku Pengelolaan Keuangan Pribadi Mahasiswa Universitas Islam Negeri Alauddin Makassar Dengan Literasi Keuangan Sebagai Variabel Interverning. Repository.Uin-Alauddin, 151(2), 10-17. 